\section{9. 鉛曝露作業者の盆血之無酸症}

渡辺 弘, 細川 汀, 村山七早子, 山剛茂夫 (大阪市立衛研)

新聞社印刷事業場の鉛取扱作業者の貧血者に不定の胃 症状を是する者が多く，治療上にる種及の関係学有する と思われるので, 胃液酸度との相関について, 調查研究 を行なった。

1）胃液中の源離㻥酸を測定するマス・スクリーニン グの方法として，アズールーA レジン法について，若干 の基礎的䱈験㧍よび種々の疾息やその他の条件について

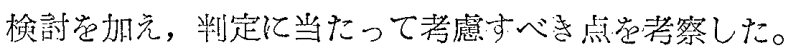

2) A 新聞社の鉛取扱者 572 名中胃症状意培光万者は 100 名 $(17.2 \%)$ で，他の作業者 469 名凹58名 (12.4\%)

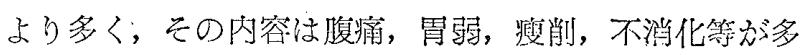


について，胃淮検查を行なったが，娊酸症は $46.9 \%$ を 示し，貧血所見宗さなかった者のうちの然酸症 23.9

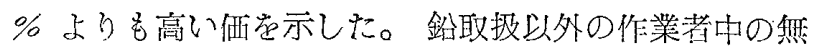
酸症は $31.8 \%$ であった。

Y 新聞社印刷局の鉛取投作業者 344 名汃引認めた貧血 渚19名（ての中 20 才尚男子 9 名，女子 5 名であった）中 の無酸症は $31.6 \%$ であった。

この然酸症について, 胃X線透視, 血清鉄, 鉄投与效 果等堂あわ教虑を行なった。

3）対照として，C発電所 1282 名中から発茪された 貧血者92名について行なった成績では，然酸症は 42.9 \%で，いずれの年令層でも，貧血壱認めない者よりも高 い俩走示した。乙の貧血站鉄剂投与により，3 月で約75 \%に效果を示したが，無酸将:の方が不良の傾向を示し た。

\section{8. 疏化鉛の畵性について}

館 正知（岐阜医大・公衛）

西埋俊籍（三来金属，神岡鉱山）

從芽，水に不溶性であるととから，埥性か少ないと考

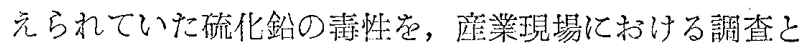
動物実䀦とて論ずる。

1）岐㚖县下鉱Iの鉛原鎕は硫化鉛の形で存在する。 これが焼成，熔鉝の過程で，澌次，酸化鉛の形に移行す 尽。即ちはじめ $99 \%$ であった PbS-Pb が一度焅きで $60.2 \%$ ，二度燒きで $17.4 \%$ 亿減少し，他方，はじめ $0.31 \%$ であった PbO-Pb が一废烧きで $17.7 \%$ ，二度 此きで $63.8 \%$ と増加する。とのような䤵種の変化と，



の測定成績とから，気中鈆の組成を算出した。

\begin{tabular}{|c|c|c|c|}
\hline & $\mathrm{PpS}-\mathrm{Pb}$ & $\mathrm{PbO}-\mathrm{Pb}$ & \\
\hline $\mathrm{T}$ 坑 内 $(\mathrm{A})$ & 0.228 & $\mid 0.00058$ & 鉱石分析值より \\
\hline $\begin{array}{l}\text { DL 焼結機 (B) } \\
\text { 点 品 炉 前 }\end{array}$ & $4.31-4.99$ & 0.220 & $\begin{array}{l}\text { 堆積麘分析値与 } \\
y\end{array}$ \\
\hline 熔銗炉附近 (C) & $0.228-0.570$ & 0.190 & " \\
\hline
\end{tabular}

PbO-Pb の结とんど無い坑内作業者にも，尿コプロポ ルフィリン弱陽性者 (43\%), 鉛縁( $8 \%$ ) 等の鉛吸収の有

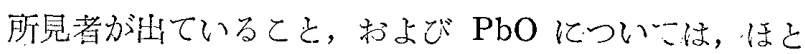

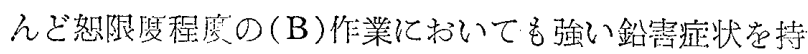
っているととから，PbS-Pb も中輩発現に参加するとと


気の強烈な作用が加わるので，身体障害はも台らん著る (い)

2）家鬼 4 頡を 2 群に分け，60日間経口的に，一方に は硫化鉛（98.4\%の純度）飞合計 $1862 \mathrm{mg}$ ，他方には酸 化鉛 $(98.4 \%$ の続度）足合計 $301 \mathrm{mg}$ 投与して，中琵発 現の状沉を徵察した。その結身，PbS-Pbは投与糸積量 で $\mathrm{PbO}-\mathrm{Pb}$ の 2.4 篮, 1 日投与量で 1.6 倍与光ると

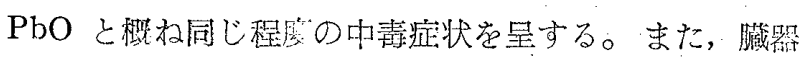
中の鉛の分析の結欇，PbS-Pbによっても，臟器中への 蓄糟か㵔明で，吸収が行な的れているととを示してい る。

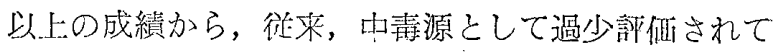
いた $\mathrm{PbS}-\mathrm{Pb}$ き，痽業鉛中毒の発現に参加するもので あるとを主脹する。

\section{1. $\mathrm{Pb}$ 及び EDTA 亡溶血}

宮田胒吾（波皋医大・公䇶）

$\mathrm{Pb}$ と赤血球と赽結合せしわた後, 详びに $\mathrm{Pb}$ と結合 した赤血球に Ca-EDTA を作用せしめた後の赤血球の 変化芭，溶血現象より検討せんと試みた。

まず，人脱紷維血液を食塩水で洗湺した後，4\%赤血 球浮游液安作り，之れに同量の $10^{-3}, 10^{-4}, 10^{-5}, 10^{-6}$. $\mathrm{Pb}$ 食塩水溶液を加党，溶血の時間的経過をしらべた。


溶血がおこりはじめ，溶血の程度は $10^{-4}, 10^{-5}, 10^{-6}$ $\mathrm{M} \mathrm{Pb}$ 濃度の順腙で小となり， $10^{-3} \mathrm{M} \mathrm{Pb}$ は $10^{-5}$ と

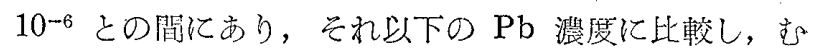
しろ溶血は阻止される。

同様な方法で $\mathrm{Pb}$ を加光た後，5,30分に Ca-EDTA 暑添加したが，赤血球の一部にただちに溶血がおてる。 5 分㷋と 30方喰とでは，後者の溶血の程度が大きい。と 
の溶血現象は検討の結果，赤血球と結合した $\mathrm{Pb}$ が除去 され，その赤血球の一部 $\left(1 / T_{50} \sim 1 / 200\right)$ が溶血したため と考充る。

この溶血は血清を加えるととによっても阻止できな い。しかし同一人の血球で，同様な方法で 4 力月後に行 なった結果では，溶血は著るしくなく，さらに 2 力月後 では，前の实験にみられた如き著炚な溶血を認めた。こ のととから，Ca-EDTA 㬄加による㴪血は恒常的では ない。

な执 Ca-EDTA に上り $\mathrm{Pb}$ 岩除去する際に，溶航 なかっった赤血球の低張食塩水付対する抵抗をしらべた。

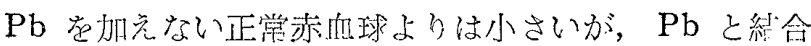
し Ca-EDTA を加光なかった赤血球よりは大であっ た。

252. 鈆，水銀投与マウスの臓器紬織呼吸，及びそれら に対する Ca-EDTA の影響

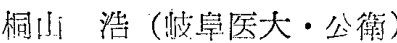

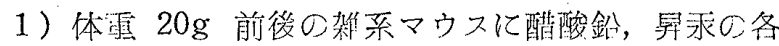
致死叟の約 $1 / 10$ 量, 即ち $13 \mathrm{mg} / \mathrm{kg}, 0.6 \mathrm{mg} / \mathrm{kg}$ 在連絖

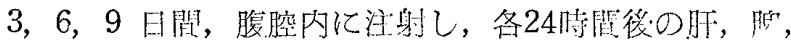

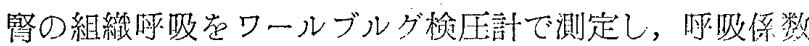
$\mathrm{Qo}_{2}$ (60分值)葆比较した。対照マウスの $\mathrm{Qo}_{2}$ 纹服 9.4, 脾 13.6，算 26.1 であったが，てれに対して，鈆投与

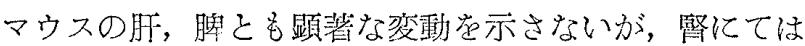
$\mathrm{QO}_{2}$ は経日的に上昇した。水鋇では肺の $\mathrm{QO}^{2}$ は濑次減

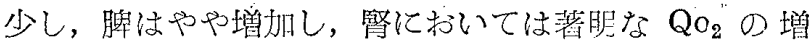
加龙見た。

2）金属程投与30分後に每:日 Ca-EDTA $3 ， 6 ， 9$ 日閒腹然内注射し，その影響を測定したが，鉛において



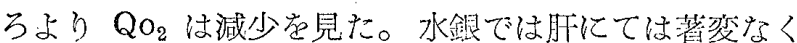
やや減少し，脾では $\mathrm{QO}_{2}$ の減少を促すが，筒では 1) と同様に $\mathrm{QO}_{2}$ の增加在㴶察し，とくに 3 日目には垚る しく増大した。

3）鉛在 9 月間の進日注射後，鉛の投与党中止した場 合の $\mathrm{QO}_{2}$ の変化を 3 日京きに3 回測定したが，肝にて

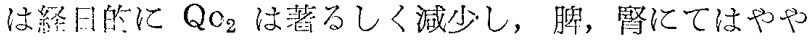
減少の傾向を示した。

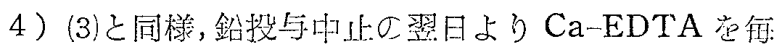

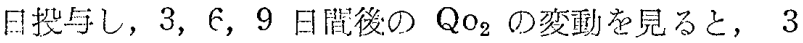
者とも次策に対照に近い $\mathrm{Qo}_{2}$ 值学示す傾后にあること がわかった。

5 ) 致死星の約 $1 / 2$ 最克刑日 2 回注射し，3，6，9日
目後の $\mathrm{Qo}_{2}$ の変動を検した。鉛，水銀ともに肝，脾， では経日的に $\mathrm{QO}_{2}$ ：減少の傾向を示すが，腎にては最 初增大するが，6日目を頂点として，9日目では $\mathrm{Qo}_{2}$ の減少を示した。

以」いずれの場合でも，とくに著明な変化を示すのは 腎であって，鈆，水銀の投与はより一般に $\mathrm{Qo}_{2}$ は著る しく増大する。これらに Ca-EDTA を作用させた場合 鉿では一般に対照值に近づくが，水銀では脾を除いては 特别な変動方涀られなかった。

\section{3. 実験的鉛的中毒に於ける 2-Mercaptoethyl- amine と Ca EDTA の効果の比較について} 大平昷彦，黒田 健（風山大・衛生）

2-Mer captsethyla mine (以下 MEA) の鉛中毒に及 ぼす効果を，Ca-EDTA の效果と比較するため，以下 の如き動物实戨を行なった。

I 鉛投与マウスの体重に及登守效果

$\mathrm{Cb} \times \mathrm{C}_{57} \mathrm{BL}$ の $\mathrm{F}_{1}$ (体重 $20 \sim 30 \mathrm{~g}$ ) 觉 1) 鉛対照群 2) MEA 処理群，3) Ca-EDTA 処理群の 3 群に分 け，备群令 10 , 우 10 , 計 20 匹ずつとした。各群恃每週 5 回 $\mathrm{Pb} 10 \mathrm{mg} / \mathrm{kg}$ ずつを背部皮下， 3 〜 時間後 1 ) 群には対照として 5\% グルコース溶液， 2）群 MEA (日本新薬製) $100 \mathrm{mg} / \mathrm{kg} ， 3$ ) 群 Ca-EDTA (第一化 学製） $150 \mathrm{mg} / \mathrm{kg}$ 学それぞれ腹腔内投与。注射菜溶媒 はすべて $5 \%$ グルコース溶液とし， $\mathrm{Pb}$ は 0.366 酢酸 鉛溶液，MEA および Ca-EDTA は $2 \%$ 溶液にした。

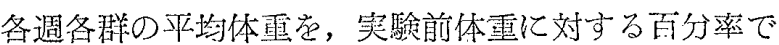
あらわせば，とくに1，4 週に扔いて MEA の效果を 認为得た。

III鉛投与マウスの生存率に及仿す效果

鉛投年量は $70 \mathrm{mg} / \mathrm{kg}$ とし，1.831 酢酸鉛溶液起使用 その他の実験条件はすべてエに準じた。，各週各群マウス の生存数を百分率であらわすと，MEA 投与は死亡開始

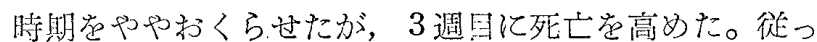
て多量の鉛投与の場合，生存率に及ぼす MEA の效果 は誌め得るに至らなかった。

III 血潹，生体内鉛分布方よび鉛排泜に及ぼす MEA の效果については目下検傠中である。 